\title{
Competencies for teacher-librarians: The Malaysian perspective
}

\section{Abrizah Abdullah;Singh, Diljit}

International Association of School Librarianship. Selected Papers from the ... Annual Conference; 2000;

Education Database

\section{Competencies for Teacher-Librarians: The Malaysian Perspective}

\author{
Abrizah Abdullah and Diljit Singh \\ Faculty of Computer Science and Information Technology \\ University of Malaya \\ Malaysia
}

\begin{abstract}
Teacher-librarians need specific competencies, knowledge, and skills in order to perform their roles effectively. Very few guidelines and standards exist, however, in developing countries for these competencies. The primary goal of this study was to determine the competencies needed by teacher-librarians in Malaysian secondary schools to effectively perform their roles. The study employed a survey methodology using a population of professionals directly involved in the field of teacher-librarianship: teacher-librarians, library educators, and supervisors. The findings present a Malaysian perspective on the roles and competencies for teacher-librarians and will also be useful in working towards an international framework of competencies.
\end{abstract}

\section{Introduction}

School libraries need trained teacher-librarians who can perform their roles effectively. A competent and effective teacher-librarian is the key to good school library service. As schools change from passive learning environments into active ones, the role of the librarian has to change as well. Teacher-librarians also have an important function in helping administrators to formalize the role of the school library. They create an awareness of the value of the school library in the community and support efforts to promote its use as an educational tool as well as a recreational facility.

The published literature indicates that the current and emerging roles of the teacherlibrarian include those of a resource information specialist, a collaborator with teachers, and a designer and implementer of effective learning programs, especially those that encourage resource-based inquiry learning. In short, the position of teacher-librarian has the potential to be one of the most valuable resources in a school: an agent of change impacting all levels of school organization and the provider of rich and interesting learning environments and opportunities.

Most school library associations in developed countries have maintained that in order to perform these roles, teacher-librarians need specific knowledge and skills that must be emphasized in their training and qualifications. While such guidelines and competency requirements have been produced in developed nations, little research has been done in developing countries. Malaysia, a developing country that is beginning to place emphasis on the development of school libraries, has many teacher-librarians that are in need of training in school librarianship. Surveys in the early 1990 s showed that many teacher-librarians had either minimal or no such training. As the country develops its training programs for teacher-librarians in an era of changes resulting from the use of information technology, there is a need for local guidelines on the attributes needed by teacher-librarians. 


\section{Review of Literature}

A constant theme in the literature by leading school library thinkers and practitioners is that the person responsible for managing the school library can make it successful or otherwise. The literature also emphasizes the roles of teacher-librarians and the importance of core competencies to perform the roles. It is significant that in those countries where school libraries are well established, there is a steady flow of research and reappraisal of these institutions. Studies of school libraries in Malaysia concentrate more on (a) documenting and suggesting improvements and (b) providing guidelines to improve the physical facilities and management of school libraries. Very little has been said about either the roles or the competencies for teacher-librarians in Malaysia.

National guidelines and the professional literature in various countries promote an active and high role for teacher-librarians. In the American context there have been numerous studies that support the importance of the role of the teacher-librarian as an information specialist. The teaching role, relating to instruction in library and information skills, has been widely discussed by Walter and Montgomery (1983), Turner (1985), Kuhlthau (1987), Eisenberg and Berkowitz (1988), Vandergrift (1994) and Putnam (1996). The importance of the instructional consultation role of the teacher-librarians has been emphasized by Walker (1988), Putnam (1996), and Information Power as well as more recent publications. Many writers also have specified the changing roles of teacher-librarians due to copputer-related technologies in the schools (Barron, 1995; Boardman, 1994; Burnett and McNally, 1996; Eisenberg and Berkowitz, 1988; Putnam, 1996).

A review of the research literature on competencies for teacher-librarians indicates that relatively little research on this topic has been conducted. Professional organizations have published several excellent guides to competencies in school librarianship that have been used by researchers in their studies of competencies. Pfister (1981) used the school library media competencies proposed by the Florida Council on Teacher Education (C.O.T.E) Task Force in his efforts to discover the essential competencies for school media preparation programs. Other studies by Schreen (1987) and Schon, Helmstadter and Robinson (1991) investigated the competencies in professional areas that teacher-librarians should have. Jowkar and Kinnell (1991) conducted a study of competencies that resulted in the development of a competency-based education programme for teacher-librarians in Iran. In his later attempt to establish a single library education programme for the education of teacher-librarians in developing countries, Jowkar (1992) utilized the competencies suggested by librarians from other regions.

\section{Research Question and Methodology}

The primary goal of this study was to determine the competencies needed by teacherlibrarians in Malaysian secondary schools in order to effectively perform their roles. The research question was to determine the perceptions of practicing teacher-librarians, school library supervisors, and library educators about the competencies required for teacher-librarians in Malaysia.

The study employed a survey methodology to elicit information from the respondents about their attitudes concerning the roles of teacher-librarians and the competencies they need to perform these roles. The population chosen for this study was focused on the professionals who are most directly involved in the field of school librarianship and who generally have first-hand knowledge of the roles and competencies required by a teacher-librarian: teacher-librarians as the practitioners, library educators as the trainers, and supervisors from Departments of Education. 
A mail questionnaire was used for data collection. The questionnaire was developed, pretested, revised, and then sent to a randomly selected sample of 20 teacher-librarians from Malaysian secondary schools, 20 library information science or educational technology educators in teacher training colleges and universities, and 20 supervisors from Departments of Education or State Education Resource Centers. The teacher-librarians, library educators, and supervisors that comprised the three groups of samples are considered representative of the population and relevant to the inquiry of the study. After one follow-up mailing, a total 47 usable questionnaires (78.3\%) were received and analyzed. The respondents included 17 teacher-librarians, 12 library educators, and 18 supervisors.

The initial section of the 13-page structured questionnaire sought the views of the respondents about the roles of teacher-librarians in Malaysia. Respondents were also asked if they believed that teacher-librarians played important roles within the school and if they agreed that the teacher-librarians needed to have specific skills to perform the roles.

The next section focused on the competencies for teacher-librarians. The items in this section, grouped under five broad areas of variables being examined, comprised 70 competency statements that teacher-librarians should perform. The competency statements covered the three areas of librarianship, management, and education, and they were adapted from the American Library Association's guidelines for the basic preparation of the school library media specialists (Curriculum, 1989) and School Librarians: Guidelines to Competency Requirements (Hannesdottir, 1996). These statements were refined and adapted to the Malaysian situation. The authors added a fourth area of competency for teacher-librarians, technology, since it is expected that teacher-librarians will play a leading role in applying information technology within the school and should therefore be familiar with the full range of educational and information technology. They also developed the fifth area, personal competencies, from suggestions in the professional literature with regard to the personality of teacher-librarians.

Respondents prioritized the role and competency statements using a five-point Likerttype scale. They also indicated the level of each competency (i.e., high, intermediate, or basic) that the teacher-librarians must meet in order to perform their roles. The authors used SPSS 7.5 for Windows to analyze the data collected.

\section{Findings}

\section{Roles of Teacher-librarians}

It was found that at least $75 \%$ of the respondents agreed with the published literature on the roles of teacher-librarians. There was a high agreement among the three groups of respondents that the primary role of the teacher-librarians was to assist students in the traditional and electronic methods of identifying, assessing, and retrieving information. A high majority of the respondents strongly agreed that teacher-librarians played important roles and needed specific skills to perform these roles within the school. 
Table 1 presents the roles of teacher-librarians in ranked order compared by sub-groups.

Table 1

Roles of Teacher-librarians in Ranked Order

\begin{tabular}{|c|c|c|c|}
\hline \multirow[t]{2}{*}{ Statement of teacher-librarian roles: } & \multicolumn{3}{|c|}{ Rank order } \\
\hline & $\mathrm{TL}^{*}$ & $\mathrm{LE}^{*}$ & $\mathrm{~S}^{*}$ \\
\hline $\begin{array}{l}\text { 1. Assist students in traditional and electronic methods of } \\
\text { identifying and assessing information in the school library. }\end{array}$ & 2 & 1 & 1 \\
\hline 2. Assist students in interpreting information. & 4 & 6 & 10 \\
\hline $\begin{array}{l}\text { 3. Inform teachers, students and administrators of new material } \\
\text { /equipment / services. }\end{array}$ & 2 & 1 & 1 \\
\hline 4. Instruct students in locating information. & 1 & 6 & 1 \\
\hline 5. Instruct students in evaluating information. & 8 & 9 & 7 \\
\hline 6. Instruct students in communicating information. & 10 & 10 & 9 \\
\hline $\begin{array}{l}\text { 7. Provide teachers with in-service opportunities (e.g. } \\
\text { introduction to new technology, use / production of media) }\end{array}$ & 4 & 1 . & 1 \\
\hline $\begin{array}{l}\text { 8. Teach with a variety of modes and media, thus modeling } \\
\text { instruction techniques for other teachers. }\end{array}$ & 4 & 6 & 1 \\
\hline $\begin{array}{l}\text { 9. Participate in school and district curriculum development and } \\
\text { assessment. }\end{array}$ & 8 & 1 & 7 \\
\hline $\begin{array}{l}\text { 10. Consult with teachers about incorporating information } \\
\text { materials and skills into the classroom. }\end{array}$ & 4 & 1 & 1 \\
\hline
\end{tabular}

$\left({ }^{*} \mathrm{TL}=\right.$ Teacher-librarian; LE $=$ Library Educator; $\mathrm{S}=$ Supervisor $)$

\section{Competencies for Teacher-librarians}

To determine the essential competencies for teacher-librarians, the returns were examined and each competency that met the C.O.T.E. standard (Pfister, 1981; Curriculum; 1989) was considered essential. That standard requires that " $85 \%$ of all respondents must consider the competencies very important (very useful) with $51 \%$ considering it essential" for it to be regarded as an essential competency. An overview of the findings is presented in Table 2.

Table 2

Competencies Considered Essential and Non-essential

\begin{tabular}{|c|c|c|}
\hline Essential (17 of 61) & $\begin{array}{c}\text { Rejected overall but } \\
\text { thought essential by one } \\
\text { or more sub- } \\
\text { groups (12 of } 61)\end{array}$ & $\begin{array}{c}\text { Rejected overall and } \\
\text { rejected by every sub- } \\
\text { group (32 of 61) }\end{array}$ \\
\hline
\end{tabular}

Based on the C.O.T.E. standard, only 17 of the 61 competencies from the literature were considered to be essential by at least $51 \%$ of the survey respondents. The $85 \%$ requirement was not met at all, unlike the study conducted by Pfister (1981). Twelve of the remaining 44 proposed competencies were thought to be essential by one or more sub-groups. Thirty-two competencies consistently received rankings at the lower end of 
the scale. These competencies were considered non-essential in that they were rejected overall as well as by all three sub-groups. The 17 competency statements that met the C.O.T.E. definition of essential, and their frequency and percentage responses in ranked order, are presented in Table 3.

Table 3

Competencies Rated Most Frequently as Essential $(n=47)$

\begin{tabular}{|c|c|c|}
\hline Competency: The ability to & Freq & $\%$ \\
\hline $\begin{array}{l}\text { 1. Utilize classification principles and organize the materials } \\
\text { according to standard classification scheme. }\end{array}$ & 37 & 78.7 \\
\hline $\begin{array}{l}\text { 2. Apply appropriate standards and guidelines to develop and } \\
\text { evaluate library collections. }\end{array}$ & 35 & 74.5 \\
\hline $\begin{array}{l}\text { 3. Prepare and maintain catalogue of the collection according to } \\
\text { appropriate standard cataloguing principles. }\end{array}$ & 34 & 72.3 \\
\hline $\begin{array}{l}\text { 4. Index the available material and make the information sources } \\
\text { in the collection fully available for subject/author/title } \\
\text { searching. }\end{array}$ & 32 & 68.1 \\
\hline $\begin{array}{l}\text { 5. Co-operate with teachers in the development and evaluation of } \\
\text { resources. }\end{array}$ & 31 & 66.0 \\
\hline $\begin{array}{l}\text { 6. Utilize automation for major library functions (cataloguing, } \\
\text { acquisition, circulation, etc.). }\end{array}$ & 31 & 66.0 \\
\hline $\begin{array}{l}\text { 7. Use information technology in student-learning activities } \\
\text { across the curriculum. }\end{array}$ & 29 & 61.7 \\
\hline $\begin{array}{l}\text { 8. Design, plan and produce specific resources for instructional } \\
\text { purposes where appropriate resources are not available. }\end{array}$ & 29 & 61.7 \\
\hline $\begin{array}{l}\text { 9. Develop procedures for ordering, receiving and processing the } \\
\text { learning resources. }\end{array}$ & 27 & 57.4 \\
\hline $\begin{array}{l}\text { 10. Organize and develop collections, facilities and services to } \\
\text { achieve objectives. }\end{array}$ & 27 & 57.4 \\
\hline $\begin{array}{l}\text { 11. Apply advanced technology in the storage, handling, search, } \\
\text { retrieval and use of information. }\end{array}$ & 26 & 55.3 \\
\hline 12. Effectively search CD-ROMs and the Internet. & 26 & 55.3 \\
\hline $\begin{array}{l}\text { 13. Outline school library policy, and design a program to } \\
\text { implement the policy. }\end{array}$ & 26 & 55.3 \\
\hline $\begin{array}{l}\text { 14. Apply appropriate principles to weed and inventory materials } \\
\text { and equipment. }\end{array}$ & 25 & 53.2 \\
\hline $\begin{array}{l}\text { 15. Develop guides to sources and bibliographies that assist } \\
\text { teachers and their students in their search for appropriate } \\
\text { information. }\end{array}$ & 25 & 53.2 \\
\hline $\begin{array}{l}\text { 16. Develop appropriate services for teachers and students } \\
\text { according to goals and objectives. }\end{array}$ & 24 & 51.1 \\
\hline $\begin{array}{l}\text { 17. Evaluate and use computers and related IT technology for } \\
\text { instruction. }\end{array}$ & 24 & 51.1 \\
\hline
\end{tabular}

Of the 17 essential competencies, 12 were in the area of librarianship (Table 3 , Items $1,2,3,4,5,6,8,9,11,12,14,15$ ), three were management-oriented competencies (Table 3 , Items 10,13,16), and two were technology-oriented competencies (Table 3, Items 7 and 17). Education-oriented competencies were not rated high enough to be considered essential overall.

Analysis of the competencies rated essential revealed some variations among the sub-groups (Table 4). It was found that library or technology educators' ratings are more apt to differ significantly. This could be have been brought about by their academic qualifications and experience in librarianship. The library educators emphasized the use 
of information technology in learning and management skills while the teacher-librarians and supervisors stressed practical library and management skills. Teacher-librarians focused on the need to apply standards and guidelines for collection development. Supervisors focused on the need to apply standard principles in the organization of materials. Library educators focused on the ability to apply information technology to major library functions. It is interesting to note that two competencies highly rated as essential by the library educators (Table 4, Library educators - Items 2 and 3) were not considered essential overall by the other two sub-groups. 
Table 4

Competencies Rated as Essential by Sub-Groups

\begin{tabular}{|c|c|}
\hline Competency: The ability to & $\%$ \\
\hline \multicolumn{2}{|l|}{ Teacher-librarians $(\mathrm{n}=17)$} \\
\hline $\begin{array}{l}\text { 1. Apply appropriate standards and guidelines to develop and evaluate } \\
\text { library collections. }\end{array}$ & 82.4 \\
\hline 2. Utilize classification principles and organize the materials according to & 70.6 \\
\hline standard classification scheme. & 706 \\
\hline $\begin{array}{l}\text { 3. Prepare and maintain cataiogue or the collection accoraing to } \\
\text { appropriate standard cataloguing principles. }\end{array}$ & \\
\hline 4. Index the available material and make the information sources in the & 70.6 \\
\hline $\begin{array}{l}\text { collection fully available for subject / author / title searching. } \\
\text { 5. Co-operate with teachers in the development and evaluation of resources }\end{array}$ & 70.6 \\
\hline \multicolumn{2}{|l|}{ Supervisors $(\mathrm{n}=18)$} \\
\hline $\begin{array}{l}\text { 1. Utilize classification principles and organize the materials according to } \\
\text { standard classification scheme. }\end{array}$ & 83.3 \\
\hline $\begin{array}{l}\text { 2. Prepare and maintain catalogue of the collection according to } \\
\text { appropriate standard cataloguing principles. }\end{array}$ & 75.0 \\
\hline $\begin{array}{l}\text { 3. Apply appropriate standards and guidelines to develop and evaluate } \\
\text { library collections. }\end{array}$ & 75.0 \\
\hline $\begin{array}{l}\text { 4. Design, plan and produce specific resources for instructional purposes } \\
\text { where appropriate resources are not available. }\end{array}$ & 75.0 \\
\hline $\begin{array}{l}\text { 5. Co-operate with teachers in the development and evaluation of } \\
\text { resources. }\end{array}$ & 66.7 \\
\hline \multicolumn{2}{|l|}{ Library Educators $(n=12)$} \\
\hline $\begin{array}{l}\text { 1. Utilize automation for major library functions (cataloguing, acquisition, } \\
\text { circulation etc.). }\end{array}$ & 88.9 \\
\hline $\begin{array}{l}\text { 2. Establish long-term and short-term goals for the development of the } \\
\text { library. }\end{array}$ & 77.8 \\
\hline $\begin{array}{l}\text { 3. Study and assess the information needs and interests of teachers and } \\
\text { students. }\end{array}$ & 72.2 \\
\hline 4. Effectively search CD-ROMs and the Internet. & 72.2 \\
\hline $\begin{array}{l}\text { 5. Use information technology in student-learning activities across the } \\
\text { curriculum. }\end{array}$ & 66.7 \\
\hline
\end{tabular}

The results of this study in terms of personal competencies are similar to those of Jowkar (1992). The respondents indicated that the most important personal competencies needed by teacher-librarians were a commitment to excellence, the ability to communicate, and an enthusiasm for information resources and communication media. The respondents in this study gave high value to the category of personal competencies, indicating the serious need for this type of competency among teacher-librarians (Table 5). Some respondents also suggested additional personal competencies that they felt were needed by teacher-librarians such as integrity, patience, responsibility, initiative, willingness to learn, and self-motivation. 
Table 5

Personal Competencies Expressed as "Needed" or "Somewhat Needed"

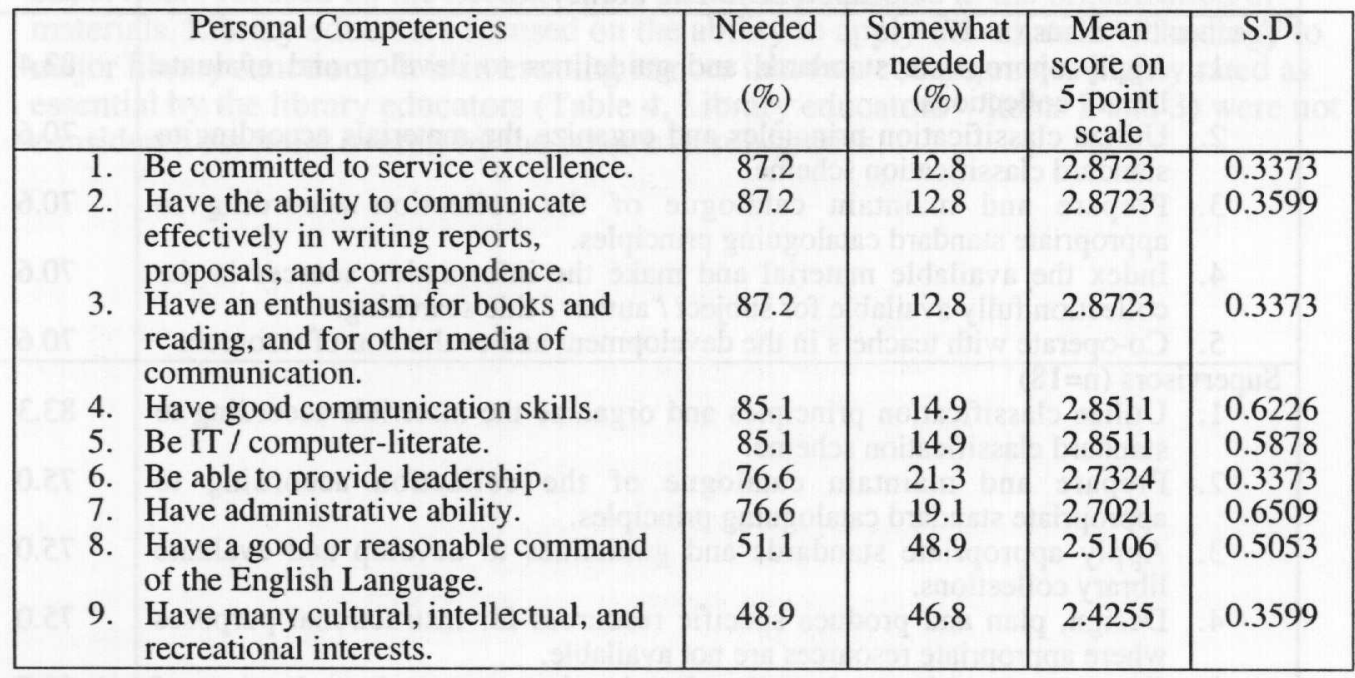

\section{Level of Skills for Essential Competencies}

The survey also aimed to determine the level of competency that teacherlibrarians must meet in order to perform their roles. The results focused only on the 17 competencies that met the definition of 'essential' by the C.O.T.E. standard. About $90 \%$ of the respondents felt that the level of skills for the 17 essential competencies should be at least at the intermediate level, and half of them chose a high level of skill for these competencies. Analysis of the levels of skills for essential competencies revealed some differences among the sub-groups. More than $50 \%$ of the supervisors rated all 17 competencies as requiring high level of skill. At least $50 \%$ of the library educators rated 15 of the 17 essential competencies as requiring high level of skill. However, only nine competencies were viewed as requiring high level of skill by at least $50 \%$ of the teacherlibrarians. Table 6 shows the responses to the 17 essential skills by the three sub-groups. A majority of each sub-group perceived that the competencies requiring a high level of competency were those that related to librarianship. The results also show that more library educators and supervisors than teacher-librarians perceived the competencies as requiring a high level of skill. 
Table 6

Essential Competencies Requiring High Level of Skill by Sub-group

\begin{tabular}{|c|c|c|c|}
\hline Competency: The ability to & $\begin{array}{c}\text { Teacher } \\
\text { Librarians } \\
\%\end{array}$ & $\begin{array}{c}\text { Library } \\
\text { educators } \\
\%\end{array}$ & $\begin{array}{c}\text { Supervisors } \\
\%\end{array}$ \\
\hline $\begin{array}{l}\text { 1. Utilize classification principles and organize } \\
\text { the materials according to standard } \\
\text { classification scheme. }\end{array}$ & 82.4 & 91.7 & 94.4 \\
\hline $\begin{array}{l}\text { 2. Apply appropriate standards and guidelines to } \\
\text { develop and evaluate library collections. }\end{array}$ & 64.7 & 91.7 & 83.3 \\
\hline $\begin{array}{l}\text { 3. Prepare and maintain catalogue of the } \\
\text { collection according to appropriate standard } \\
\text { cataloguing principles. }\end{array}$ & 82.4 & 91.7 & 83.3 \\
\hline $\begin{array}{l}\text { 4. Index the available material and make the } \\
\text { information sources in the collection fully } \\
\text { available for subject / author / title searching. }\end{array}$ & 64.7 & 66.7 & 88.9 \\
\hline $\begin{array}{l}\text { 5. Co-operate with teachers in the development } \\
\text { and evaluation of resources. }\end{array}$ & 58.8 & 91.7 & 66.7 \\
\hline $\begin{array}{l}\text { 6. Utilize automation for major library functions } \\
\text { (cataloguing, acquisition, circulation, etc.). }\end{array}$ & 64.7 & 50.0 & 72.2 \\
\hline $\begin{array}{l}\text { 7. Use information technology in student- } \\
\text { learning activities across the curriculum. }\end{array}$ & 47.1 & 66.7 & 77.8 \\
\hline $\begin{array}{l}\text { 8. Design, plan and produce specific resources } \\
\text { for instructional purposes where appropriate } \\
\text { resources are not available. }\end{array}$ & 23.5 & 58.3 & 77.8 \\
\hline $\begin{array}{l}\text { 9. Develop procedures for ordering, receiving } \\
\text { and processing the learning resources. }\end{array}$ & 47.1 & 66.7 & 50.0 \\
\hline $\begin{array}{l}\text { 10. Organize and develop collections, facilities } \\
\text { and services to achieve objectives. }\end{array}$ & 52.9 & 83.3 & 61.1 \\
\hline $\begin{array}{l}\text { 11. Apply advanced technology in the storage, } \\
\text { handling, search, retrieval and use of } \\
\text { information. }\end{array}$ & 35.3 & 50.0 & 61.1 \\
\hline 12. Effectively search CD-ROMs and the Internet. & 41.2 & 50.0 & 66.7 \\
\hline $\begin{array}{l}\text { 13. Outline school library policy, and design a } \\
\text { programme to implement the policy. }\end{array}$ & 29.4 & 83.3 & 66.7 \\
\hline $\begin{array}{l}\text { 14. Apply appropriate principles to weed and } \\
\text { inventory materials and equipment. }\end{array}$ & 58.8 & 33.3 & 61.1 \\
\hline $\begin{array}{l}\text { 15. Develop guides to sources and bibliographies } \\
\text { that assist teachers and their students in their } \\
\text { search for appropriate information. }\end{array}$ & 47.1 & 58.3 & 61.1 \\
\hline $\begin{array}{l}\text { 16. Develop appropriate services for teachers and } \\
\text { students according to goals and objectives. }\end{array}$ & 52.9 & 100.0 & 78.8 \\
\hline $\begin{array}{l}\text { 17. Evaluate and use computers and related IT } \\
\text { technology for instruction. }\end{array}$ & 35.3 & 41.7 & 72.2 \\
\hline
\end{tabular}




\section{Significance of Findings}

The researchers believe that the information and knowledge generated from this study are essential for effective operation of school libraries. Since the study has identified key areas of knowledge and skills considered to be essential for teacherlibrarians, library educators and school library supervisors may use it to develop or upgrade programs for the comprehensive preparation of teacher-librarians. Training institutions, such as colleges and departments of education, now have a basis for discussing the competencies required for teacher-librarians and can use the findings as a starting point for reviewing training requirements. The study will also help practicing and potential teacher-librarians to recognize the necessary competencies and will serve as a basis for self-assessment and improvement of skills.

At this point in time when Malaysians are rapidly entering the information society and getting connected to the information superhighway, especially in the light of the Smart Schools project, it is important that teacher-librarians have technological competencies and be prepared for the challenges presented by new and emerging technologies. Empirically determined competencies should lead to better preparation of school library manpower for future schools.

It is hoped this study will also be a stimulus for studies in other countries regarding the competencies for teacher-librarians. The findings will also be useful in working towards an international framework of competencies, especially for developing countries. More input and research is still needed to achieve this, including input from teachers, principals and students. It is hoped that the findings of studies like this can eventually form the basis for teacher-librarian training programs internationally.

\section{Conclusion}

This study has presented a Malaysian perspective on the competencies needed by teacher-librarians. It supports the view that teacher-librarianship requires specifically defined knowledge and skills. Based on this study, it is also clear that competencies in specific areas other than traditional librarianship, such as management and information technology, need attention in library and information science education programs so that teacher-librarians will be better able to carry out their responsibilities.

\section{Acknowledgement}

The authors wish to thank the Faculty of Computer Science and Information Technology, University of Malaya for providing an environment conducive to research. 


\section{References}

Barron, D.B. (1995). May the force be with you: School library specialists and technology. School Library Activities Monthly, 11 (May), 48-50.

Boardman, E.M. (1994). Turn, turn, turn,....but still finding the answers. Book Report, 13(2), 11-13.

Burnett, K. \& McNally, M.J. (1996). School library media specialist as knowledge navigator In The virtual school library: Gateway to the information superhighway. Englewood, CO: Libraries Unlimited.

Curriculum folio guidelines for the NCATE review process: For the school library media specialist basic preparation (1989). Chicago: AASL/ALA.

Eisenberg, M.B. \& Berkowitz, R.E. (1988). Curriculum initiative: An agenda and strategy for library media programs. Norwood, NJ: Ablex.

Hannesdottir, S.K. (1996). School librarians: Guidelines for competency requirements. The Hague, Netherlands: IFLA.

Jowkar A. (1992). A comparison between competencies deemed necessary for teacher-librarians in Iran and those suggested by librarians from developing countries. Education Libraries Journal, 36(3), 4757.

Jowkar, A. \& Kinnell, M. (1991). Teacher-librarians and new curriculum needs in Iran. Education Libraries Journal, 35(1), 11-19.

Kuhlthau, C. (1987). Information skills for an information society: A review of the research. (ERIC Document Reproduction Service No. ED 297 740)

Pfister, F. (1981). Competencies essential for school media specialists. Journal of Education for Librarianship, 23(1), 29-42.

Putnam, E. (1996). The instructional consultant role of the school library media specialist and the effects of program scheduling on its practice. School Library Media Quarterly, 25(1), 43-47.

Schon, I., Helmstadter, G.C., \& Robinson, D. (1991). The role of school library media specialists. School Library Media Quarterly, 19(4), 228-233.

Turner, P. (1985). Helping teachers teach. Littleton, CO: Libraries Unlimited.

Vandergrift, K.E. (1994). Power teaching: A primary role of the school library media specialist. Chicago: American Library Association.

Walker, S. (1988). Information Power: The roles of the school library media specialists. School Library Media Quarterly, 17(1), 21-23.

Walter, T. \& Montgomery, P. (1983). Teaching media skills. Littleton, CO: Libraries Unlimited. 